Annals of Plant and Soil Research 22(4): 420-424 (2020)

https://doi.org/10.47815/apsr.2020.10015

\title{
Management of phosphorus and potassium in bidi tobacco (Nicotiana tabacum L.) under rainfed conditions
}

\section{S. JAFFAR BASHA ${ }^{*}$, P. PULLI BAI, K. PRABHAKAR, J. MANJUNATHS, KASTURI KRISHNA ${ }^{1}$ AND C. CHANDRASEKHARA RAO ${ }^{1}$}

\author{
Regional Agricultural Research Station, Acharya N. G. Ranga Agricultural University \\ Nandyal-518502, Kurnool District, Andhra Pradesh, India
}

Received: June, 2020; Revised accepted: August, 2020

\begin{abstract}
A field experiment was undertaken at Regional Agriculture Research Station, Nandyal, Andhra Pradesh for four consecutive seasons from 2015-16 to 2018-19 on Vertisols under rainfed condition to find out the economics and management of phosphorus and potassium in bidi tobacco (Nicotiana tabacum L.) for higher cured leaf yield and quality. The experiment was laid out in a randomized block design with 8 treatments and replicated thrice. The data pooled over four seasons revealed that significantly higher leaf length $(42.8 \mathrm{~cm})$ and leaf width $(17.3 \mathrm{~cm})$ was recorded with $100 \%$ RDF (110 kg N $\left.+70 \mathrm{~kg} \mathrm{P}_{2} \mathrm{O}_{5}+50 \mathrm{~kg} \mathrm{~K}_{2} \mathrm{O} \mathrm{ha}{ }^{-1}\right)$ every year. Significantly higher cured leaf yield $\left(1551 \mathrm{~kg} \mathrm{ha}^{-1}\right)$ and net returns (Rs 63,375 ha-1) were recorded with application of $110 \mathrm{~kg} \mathrm{~N}+70 \mathrm{~kg}$ $\mathrm{P}_{2} \mathrm{O}_{5}+50 \mathrm{~kg} \mathrm{~K}_{2} \mathrm{O}$ ha ${ }^{-1}$ every year and on par with $100 \%$ RDN $\left(110 \mathrm{~kg} \mathrm{~N} \mathrm{ha}^{-1}\right)+\mathrm{PK}\left(70 \mathrm{~kg} \mathrm{P}_{2} \mathrm{O}_{5}+50 \mathrm{~kg}\right.$ $\mathrm{K}_{2} \mathrm{O}$ ha $^{-1}$ ) once in two years (1408 kg ha-1and net returns of Rs $59,275 \mathrm{ha}^{-1}$ ). Leaf chemical constituents namely nicotine, reducing sugars and chlorides did not differ significantly due to different treatments and were in permissible limit. Post harvest soil analysis indicated that soil available $\mathrm{N}$, $\mathrm{P}_{2} \mathrm{O}_{5}$ and $\mathrm{K}_{2} \mathrm{O}$ differed significantly due to different treatments and maximum amounts of available $\mathrm{N}$ $\left(158.9 \mathrm{~kg} \mathrm{ha}^{-1}\right)$, available $\mathrm{P}_{2} \mathrm{O}_{5}\left(56.3 \mathrm{~kg} \mathrm{ha}^{-1}\right)$ and available $\mathrm{K}_{2} \mathrm{O}\left(537.3 \mathrm{~kg} \mathrm{ha}^{-1}\right)$ were recorded under treatment T5, T3 and T5, respectively. Soil pH and EC values were not affected significantly with the various treatments.
\end{abstract}

Keywords: Bidi tobacco, phosphorus, potassium, cured leaf yield, soil fertility

\section{INTRODUCTION}

The bidi tobacco (Nicotiana tabacum L.) plant requires large quantities of primary nutrients such as nitrogen $(N)$, phosphorous $(P)$, and potassium $(K)$ in order to attain high leaf yield and good quality. Soil depletion of macronutrients is plausible because of the large input requirement to the tobacco crop (Hoyos et al., 2015). Optimum tobacco growth can only be achieved with adequate and well timed nutrient supply under favorable environments. Recently, investigators have reported a decline in soil macronutrients such as $\mathrm{K}, \mathrm{P}$, and $\mathrm{S}$ after tobacco cultivation (Moula et al., 2018). The release of nicotine into the rhizosphere was considered to have a major impact on the increase or decrease of these nutrients. Thus, nicotine $\left(\mathrm{C}_{10} \mathrm{H}_{14} \mathrm{~N}_{2}\right)$ released in the soil could be mineralized and increase $\mathrm{N}$ in the soils, however, since nicotine is acidic, when mineralized could also influence solubilization of
$\mathrm{P}$ and $\mathrm{K}$ to be readily available to the plant and reduce their levels in the soil. The nutrient $P$ is essential for hastening tobacco root development as well as improvement of the color and quality of leaves. Maintaining an adequate $P$ concentration in the soil solution is necessary for improved yield and quality of tobacco. The nutrient $\mathrm{K}$ influences leaf yield and quality of the tobacco (Yang et al., 2007). However, Vann et al. (2013) indicated that the residual soil $\mathrm{K}$ and soil texture make it challenging to establish the actual amount of $\mathrm{K}$ to be supplied to optimize yields especially for the new cultivars bred as higher yielding. Standard bidi tobacco production requires $110 \mathrm{~kg} \mathrm{~N}, 70 \mathrm{~kg} \mathrm{P}_{2} \mathrm{O}_{5}$ and $50 \mathrm{~kg} \mathrm{~K}_{2} \mathrm{O} \mathrm{ha}^{-}$ ${ }^{1}$ which is closely dependent on mineral nutrient supply. Fertilization also plays a key role in influencing the most important quality parameters such as leaf colour, texture, hygroscopic properties, combustibility, nicotine, reducing sugars and chlorides contents. Keeping these observations in view, the present ${ }^{1} I C A R$ - 
investigation was designed to manage the application of phosphorus and potassium fertilizers for higher cured leaf yield and quality in rainfed Vertisols of Andhra Pradesh.

\section{MATERIALS AND METHODS}

A field experiment was undertaken from 2015-16 to 2018-19 at Regional Agriculture Research Station, Nandyal, Andhra Pradesh on Vertisols under rainfed condition. The soil of experimental site was medium deep black, moderately alkaline $(\mathrm{pH}-8.3)$, non saline (EC$\left.0.22 \mathrm{dSm}^{-1}\right)$, low in nitrogen (122 $\left.\mathrm{kg} \mathrm{ha}^{-1}\right)$, medium in available $\mathrm{P}_{2} \mathrm{O}_{5}\left(50.6 \mathrm{~kg} \mathrm{ha}^{-1}\right)$ and high in available $\mathrm{K}_{2} \mathrm{O}(520.6 \mathrm{~kg} \mathrm{ha})$. The 8 treatments consisted of $T_{1}$ - Control; $T_{2}-110 \mathrm{~kg} \mathrm{~N}$ $+70 \mathrm{~kg} \mathrm{P}_{2} \mathrm{O}_{5}+50 \mathrm{~kg} \mathrm{~K}_{2} \mathrm{O}$ ha $^{-1}$ (yearly); $\mathrm{T}_{3}-110$ $\mathrm{kg} \mathrm{N}+70 \mathrm{~kg} \mathrm{P}_{2} \mathrm{O}_{5} \mathrm{ha}^{-1}$ (yearly); $\mathrm{T}_{4}-110 \mathrm{~kg} \mathrm{~N}$ (yearly) $+70 \mathrm{~kg} \mathrm{P}_{2} \mathrm{O}_{5} \mathrm{ha}^{-1}$ (once in 2 years); $\mathrm{T}_{5}$ $110 \mathrm{~kg} \mathrm{~N}+50 \mathrm{~kg} \mathrm{~K}_{2} \mathrm{ha}^{-1}$ (yearly); $\mathrm{T}_{6^{-}} 110 \mathrm{~kg} \mathrm{~N}$ $\mathrm{ha}^{-1}$ (yearly) $+50 \mathrm{~kg} \mathrm{~K}_{2}$ (once in 2 years); $\mathrm{T}_{7}-110$ $\mathrm{kg} \mathrm{N}$ (yearly) $+70 \mathrm{~kg} \mathrm{P}_{2} \mathrm{O}_{5}+50 \mathrm{~kg} \mathrm{~K}_{2} \mathrm{ha}^{-1}$ (once in 2 years ) and $\mathrm{T}_{8^{-}} 110 \mathrm{~kg} \mathrm{~N} \mathrm{ha}^{-1}$ (yearly). The experiment was laid out in a randomized block design with three replications. The bidi tobacco variety (Nandyal Pogaku-1) was planted at planting geometry of $75 \mathrm{~cm} \times 75 \mathrm{~cm}$. The treatments were imposed through application of ammonium sulphate for nitrogen, single superphosphate for phosphorus and sulphate of potash for potassium. Half of the nitrogen, total phosphorus and potassiumwere applied as basal and remaining half of $\mathrm{N}$ was applied as top dressing within 30-40 days after planting. There was lower rainfall then the normal values during September - October of four years of experimentation except excess rainfall during September 2015 (78.1\%) and October 2017 $(66.2 \%)$. The total amount of rainfall received during crop growth period (nursery to harvest) was less than the normal during 2015-16 (22.6\%), 2016-17 (-6.8\%) and 2018-19 ($65.8 \%)$. Crop management practices like nursery raising, land preparation, weed control, intercultivation, de-suckering, need based plant protection and sun curing were adopted as per recommended practice. Measurements of the length, width and dry mass of the middle leaf were made at harvest according to Torrecilla et al. (1980).The leaf samples were used for estimating chemical quality constituents viz., nicotine, reducing sugars (Harvey et al., 1969) and chlorides (Hanumantha Rao et al., 1980). Post harvest soil samples were analysed for $\mathrm{pH}$, $\mathrm{EC}$ and status of available nutrients by adopting standard procedures (Jackson, 1973). The data gathered in each observation were statistically evaluated using analysis of variance (ANOVA) technique (Panse and Sukhatme 1985). The critical difference (CD) was computed to assess the significance of treatment means at $5 \%$ level of probability.

\section{RESULTS AND DISCUSSION}

\section{Growth parameters and cured leaf yield}

The data pooled over four seasons (2015-16 to 2018-19) revealed that the growth parameters and cured leaf yield differed significantly due to different treatments. Significantly higher plant height $(76.3 \mathrm{~cm})$ was recorded with $110 \mathrm{~kg} \mathrm{~N}$ (yearly) $+70 \mathrm{~kg} \mathrm{P}_{2} \mathrm{O}_{5}+$ $50 \mathrm{~kg} \mathrm{~K}_{2} \mathrm{O}$ ha $^{-1}$ (once in two years) and minimum in control $(53.2 \mathrm{~cm})$. This was due to topping plants and lower growth of plants in control (Table 1). Higher leaf length $(42.8 \mathrm{~cm})$ and leaf width $(17.3 \mathrm{~cm})$ was recorded in yearly application of $110 \mathrm{~kg} \mathrm{~N}+70 \mathrm{~kg} \mathrm{P}_{2} \mathrm{O}_{5}+50 \mathrm{~kg} \mathrm{~K} \mathrm{O}$ $\mathrm{ha}^{-1}$ and minimum in control $(30.1 \mathrm{~cm} ; 12.4 \mathrm{~cm})$. This increase in these parameters may be attributed to increased availability of nutrients to the plants. Similar results were reported by Moula et al. (2018). Higher cured leaf yield (1551 $\mathrm{kg} \mathrm{ha}^{-1}$ ) was observed in yearly application of $110 \mathrm{~kg} \mathrm{~N}+70 \mathrm{~kg} \mathrm{P}_{2} \mathrm{O}_{5}+50 \mathrm{~kg} \mathrm{~K}_{2} \mathrm{O}$ ha $^{-1}$ and was on par with $110 \mathrm{~kg} \mathrm{~N}$ (yearly) $+70 \mathrm{~kg} \mathrm{P}_{2} \mathrm{O}_{5}+50$ $\mathrm{kg} \mathrm{K}_{2} \mathrm{O}$ ha $^{-1}$ (once in 2 years ) (1408 kg ha ${ }^{-1}$ ). Higher growth parameters lead to higher cured leaf yield. The control recorded lower cured leaf yield $\left(773 \mathrm{~kg} \mathrm{ha}^{-1}\right)$. Zhengxiong et al. (2010) reported that yield and quality of flue-cured tobacco were greatly affected by fertilization and especially by nitrogen $(\mathrm{N})$ and potassium (K) supplies. The lack of response to applied $\mathrm{K}_{2} \mathrm{O}$ to cured leaf yield was likely due to soils having medium to high $\mathrm{K}$ levels (Vann et al., 2012). Continuous fertilization of Oriental tobacco grown as monoculture with very large amounts of phosphate fertilizers was not an effective cultural practice (Bozhinova, 2016). 
Table 1: Effect of $P$ and $K$ fertilizers on growth, cured leaf yield and economics of bidi tobacco

\begin{tabular}{|c|c|c|c|c|c|c|c|c|}
\hline Treatments & $\begin{array}{c}\text { Plant } \\
\text { height } \\
(\mathrm{cm})\end{array}$ & $\begin{array}{c}\text { Leaf } \\
\text { length } \\
(\mathrm{cm})\end{array}$ & $\begin{array}{c}\text { Leaf } \\
\text { width } \\
(\mathrm{cm})\end{array}$ & $\begin{array}{c}\text { Cured leaf } \\
\text { yield }(\mathrm{kg} \\
\left.\mathrm{ha}^{-1}\right)\end{array}$ & $\begin{array}{c}\text { Gross } \\
\text { returns } \\
\left(\mathrm{Rs} \mathrm{ha}^{-1}\right)\end{array}$ & $\begin{array}{c}\text { Cost of } \\
\text { cultivation } \\
\left(\mathrm{Rs} \mathrm{ha}^{-1}\right)\end{array}$ & $\begin{array}{c}\text { Net } \\
\text { returns } \\
\left(\mathrm{Rs} \mathrm{ha}^{-1}\right)\end{array}$ & BCR \\
\hline $\mathrm{T}_{1}$ & 53.2 & 30.1 & 12.4 & 773 & 58050 & 33450 & 24600 & 1.74 \\
$\mathrm{~T}_{2}$ & 74.4 & 42.8 & 17.3 & 1551 & 116325 & 52950 & 63375 & 2.20 \\
$\mathrm{~T}_{3}$ & 71.4 & 39.9 & 16.2 & 1391 & 104325 & 44950 & 59375 & 2.32 \\
$\mathrm{~T}_{4}$ & 66.8 & 39.6 & 16.2 & 1293 & 96975 & 42700 & 54275 & 2.27 \\
$\mathrm{~T}_{5}$ & 70.7 & 40.1 & 16.5 & 1253 & 93975 & 48450 & 45525 & 1.94 \\
$\mathrm{~T}_{6}$ & 68.8 & 40.5 & 16.3 & 1275 & 95625 & 44450 & 51175 & 2.15 \\
$\mathrm{~T}_{7}$ & 76.3 & 42.3 & 17.0 & 1408 & 105975 & 46700 & 59275 & 2.27 \\
$\mathrm{~T}_{8}$ & 70.0 & 38.3 & 16.0 & 1058 & 79350 & 40450 & 38900 & 1.96 \\
$\mathrm{~S} . \mathrm{Em}_{ \pm}$ & 3.5 & 1.8 & 0.8 & 83 & & & & \\
$\mathrm{CD}(\mathrm{P}=0.05)$ & 10.2 & 5.3 & 2.3 & 249 & & & & \\
$\mathrm{CV}(\%)$ & 9.5 & 9.0 & 10.2 & 12.3 & & & & \\
\hline
\end{tabular}

\section{Economics}

Higher net returns higher net returns (Rs $63,375 \mathrm{ha}^{-1}$ ) with benefit: cost ratio of 2.20 was recorded with yearly application of $110 \mathrm{~kg} \mathrm{~N}+70$ $\mathrm{kg} \mathrm{P}_{2} \mathrm{O}_{5}+50 \mathrm{~kg} \mathrm{~K}_{2} \mathrm{O}$ ha $^{-1}$ followed by yearly application of $110 \mathrm{~kg} \mathrm{~N}+70 \mathrm{~kg} \mathrm{P}_{2} \mathrm{O}_{5} \mathrm{ha}^{-1}$ (Rs 63,375 ha $^{-1}$ with BCR of 2.32) (Table 1). The wide differences in gross returns and net returns due to various treatments were owing to differences in their performance towards growth and yield of cured leaf. Thus, the differences in yield obtained from the various treatments were responsible to finalise the ultimate net income. Lower net returns of Rs 24,600 ha $^{-1}$ with BCR of 1.74 was observed with control. This may be attributed to lower production of cured leaf under control.

\section{Leaf chemical constituents}

The leaf chemical parameters viz., nicotine, reducing sugars and chlorides did not differ significantly due to different topping crop stage and leaf number (Table 2). The leaf chemical parameters were in permissible limits with nicotine ranging from 5.07 to $5.35 \%$ whereas reducing sugars was from 2.94 to 3.45 $\%$ and chlorides from 1.24 to 1.49 per cent. Nicotine content tended to decrease with treatments and maximum value (5.32\%) was recorded under control. On the other hand the maximum values of reducing sugars $(3.45 \%)$ and chlorides (1.49\%) were recorded with yearly application of $110 \mathrm{~kg} \mathrm{~N}+70 \mathrm{~kg} \mathrm{P}_{2} \mathrm{O}_{5}+50 \mathrm{~kg}$ $\mathrm{K}_{2} \mathrm{O}$ ha $^{-1}$. Reducing sugar content was not affected by $\mathrm{K}_{2} \mathrm{O}$ application. Reducing sugar levels were not typically correlated with $\mathrm{K}_{2} \mathrm{O}$ rate within a rate range where no yield effect was observed (Vann et al., 2012).

Table 2: Effect of $\mathrm{P}$ and $\mathrm{K}$ fertilizers on leaf chemical constituents of bidi tobacco

\begin{tabular}{|c|c|c|c|}
\hline Treatments & Nicotine (\%) & Reducing sugars (\%) & Chlorides (\%) \\
\hline $\mathrm{T}_{1}$ - Control & 5.32 & 3.39 & 1.24 \\
\hline $\mathrm{T}_{2^{-}} 110 \mathrm{~kg} \mathrm{~N}+70 \mathrm{~kg} \mathrm{P}_{2} \mathrm{O}_{5}+50 \mathrm{~kg} \mathrm{~K}_{2} \mathrm{O} \mathrm{ha}^{-1}$ (yrly) & 5.13 & 3.45 & 1.49 \\
\hline $\mathrm{T}_{3^{-}}-110 \mathrm{~kg} \mathrm{~N}+70 \mathrm{~kg} \mathrm{P}_{2} \mathrm{O}_{5} \mathrm{ha}^{-1}$ (yrly) & 5.27 & 3.15 & 1.45 \\
\hline $\mathrm{T}_{4}-110 \mathrm{~kg} \mathrm{~N}$ (yrly) $+70 \mathrm{~kg} \mathrm{P}_{2} \mathrm{O}_{5} \mathrm{ha}^{-1}$ (once in $2 \mathrm{yrs}$ ) & 5.17 & 3.12 & 1.22 \\
\hline $\mathrm{T}_{5}-110 \mathrm{~kg} \mathrm{~N}+50 \mathrm{~kg} \mathrm{~K}_{2} \mathrm{O} \mathrm{ha}^{-1}$ (yrly) & 5.15 & 3.15 & 1.26 \\
\hline $\mathrm{T}_{6}-110 \mathrm{~kg} \mathrm{~N}$ (yrly) $+50 \mathrm{~kg} \mathrm{~K}_{2} \mathrm{O}$ ha $^{-1}$ (once in $2 \mathrm{yrs}$ ) & 5.25 & 3.26 & 1.27 \\
\hline $110 \mathrm{~kg} \mathrm{~N}$ (yrly) $+70 \mathrm{~kg} \mathrm{P}_{2} \mathrm{O}_{5}+50 \mathrm{~kg} \mathrm{~K}_{2} \mathrm{O} \mathrm{ha}^{-1}$ (once in $2 \mathrm{yrs}$ ) & 5.35 & 3.19 & 1.22 \\
\hline $\mathrm{T}_{8^{-}} 110 \mathrm{~kg} \mathrm{~N} \mathrm{ha}^{-1}$ (yrly) & 5.07 & 2.94 & 1.38 \\
\hline S.Em \pm & 0.35 & 0.25 & 0.14 \\
\hline$C D(P=0.05)$ & NS & NS & NS \\
\hline CV (\%) & 11.7 & 13.2 & 17.2 \\
\hline
\end{tabular}




\section{Soil fertility}

The values of soil chemical properties of post harvest soil were compared with initial values. There was no significant change in $\mathrm{pH}$ and EC due to different treatments (Table 3 ). The effect of various treatments was statistically at par with each other including initial values. There was an improvement in available nitrogen with various treatments $\left(133.8\right.$ - $\left.158.9 \mathrm{~kg} \mathrm{ha}^{-1}\right)$ compared to initial value $\left(122.4 \mathrm{~kg} \mathrm{ha}^{-1}\right)$. The increase in soil $\mathrm{N}$ could have been caused by the mineralization, nitrification, and nicotine released in the soils, that inhibited soil bacteria with a role of converting nitrate into the inorganic form and hence $\mathrm{N}$ mineralization rate reduced causing an increase of soil total N (Farooq et al.,
2014). It is likely that the tobacco plant creates a favorable environment for increasing $N$ in the rhizosphere as this nutrient is required for nicotine synthesis. Available $\mathrm{P}$ content in soil ranged from 31.7 to $56.3 \mathrm{~kg} \mathrm{ha}^{-1}$ and maximum value was recorded with yearly application of $110 \mathrm{~kg} \mathrm{~N}+70 \mathrm{~kg} \mathrm{P}_{2} \mathrm{O}_{5} \mathrm{ha}^{-1}$. Therefore, these findings indicated that cultivation of tobacco caused a decrease in $\mathrm{P}$ (Lisuma et al., 2020). Available $\mathrm{K}$ content in soil ranged from 370.1 to $537.1 \mathrm{~kg} \mathrm{ha}^{-1}$ and maximum value was recorded with yearly application of $110 \mathrm{~kg} \mathrm{~N}+50 \mathrm{~kg}$ $\mathrm{P}_{2} \mathrm{O}_{5}$ ha $^{-1}$ Application of fertilizer did not increase $\mathrm{K}$ levels in soil due to the genetic nature of tobacco plants requiring $\mathrm{K}$ for increasing leaf yield and quality (Yang et al., 2007).

Table 3: Effect of $\mathrm{P}$ and $\mathrm{K}$ fertilizers on post harvest soil chemical properties

\begin{tabular}{|c|c|c|c|c|c|}
\hline \multirow[t]{2}{*}{ Treatment } & \multirow[t]{2}{*}{$\mathrm{pH}$} & \multirow{2}{*}{$\begin{array}{c}E C \\
\left(\mathrm{dSm} \mathrm{m}^{-1}\right)\end{array}$} & \multicolumn{3}{|c|}{$\begin{array}{c}\text { Available nutrients } \\
\left(\mathrm{kg} \mathrm{ha}^{-1}\right)\end{array}$} \\
\hline & & & $\mathrm{N}$ & $\mathrm{P}_{2} \mathrm{O}_{5}$ & $\mathrm{~K}_{2} \mathrm{O}$ \\
\hline $\mathrm{T}_{1}$ - Control & 8.1 & 0.21 & 87.8 & 31.7 & 370.1 \\
\hline $\mathrm{T}_{2^{-}} 110 \mathrm{~kg} \mathrm{~N}+70 \mathrm{~kg} \mathrm{P}_{2} \mathrm{O}_{5}+50 \mathrm{~kg} \mathrm{~K}_{2} \mathrm{O} \mathrm{ha}^{-1}$ (yrly) & 8.1 & 0.23 & 133.8 & 52.9 & 508.0 \\
\hline $\mathrm{T}_{3}-110 \mathrm{~kg} \mathrm{~N}+70 \mathrm{~kg} \mathrm{P}_{2} \mathrm{O}_{5} \mathrm{ha}^{-1}(\mathrm{yrly})$ & 8.2 & 0.18 & 146.3 & 56.3 & 410.1 \\
\hline $\mathrm{T}_{4}-110 \mathrm{~kg} \mathrm{~N}$ (yrly) $+70 \mathrm{~kg} \mathrm{P}_{2} \mathrm{O}_{5} \mathrm{ha}^{-1}$ (once in $2 \mathrm{yrs}$ ) & 8.2 & 0.22 & 150.5 & 43.1 & 391.9 \\
\hline $\mathrm{T}_{5^{-}} 110 \mathrm{~kg} \mathrm{~N}+50 \mathrm{~kg} \mathrm{~K}_{2} \mathrm{O} \mathrm{ha}^{-1}$ (yrly) & 8.1 & 0.18 & 158.9 & 32.9 & 537.1 \\
\hline $\mathrm{T}_{6^{-}} 110 \mathrm{~kg} \mathrm{~N}$ (yrly) $+50 \mathrm{~kg} \mathrm{~K}_{2} \mathrm{O} \mathrm{ha}^{-1}$ (once in $2 \mathrm{yrs}$ ) & 8.3 & 0.22 & 158.9 & 35.9 & 446.3 \\
\hline $\begin{array}{l}\mathrm{T}_{7}-110 \mathrm{~kg} \mathrm{~N}(\mathrm{yrly})+70 \mathrm{~kg} \mathrm{P}_{2}^{2} \mathrm{O}_{5}+50 \mathrm{~kg} \mathrm{~K}_{2} \mathrm{O}^{-1} \text { (once in } 2 \mathrm{yrs} \text { ) } \\
\mathrm{T}_{8^{-}} 110 \mathrm{~kg} \mathrm{~N} \mathrm{ha}^{-1} \text { (yrly) } \\
\mathrm{S} . \mathrm{Em} \mathrm{m}_{ \pm} \\
\mathrm{CD}(\mathrm{P}=0.05) \\
\mathrm{CV}(\%) \\
\text { Soil initial properties }\end{array}$ & $\begin{array}{l}8.2 \\
8.3 \\
0.34 \\
\text { NS } \\
7.1 \\
8.3\end{array}$ & $\begin{array}{l}0.19 \\
0.22 \\
0.01 \\
N S \\
11.6 \\
0.22\end{array}$ & $\begin{array}{l}154.7 \\
150.5 \\
8.00 \\
24.3 \\
9.7 \\
122.4\end{array}$ & $\begin{array}{c}42.3 \\
36.3 \\
2.5 \\
7.7 \\
10.6 \\
50.6\end{array}$ & $\begin{array}{c}435.5 \\
384.7 \\
23.1 \\
70.0 \\
9.2 \\
520.6\end{array}$ \\
\hline
\end{tabular}

It may be concluded from the results that the application of $100 \%$ RDN $(110 \mathrm{~kg})+\mathrm{PK}(70$ $\left.\mathrm{kg} \mathrm{P}_{2} \mathrm{O}_{5}+50 \mathrm{~kg} \mathrm{~K}_{2} \mathrm{O}\right)$ ha ${ }^{-1}$ once in two years or $100 \%$ RDN $(110 \mathrm{~kg})+\mathrm{P}\left(70 \mathrm{~kg} \mathrm{P}_{2} \mathrm{O}_{5}\right)$ ha ${ }^{-1}$ every year produced higher cured leaf yield and fetched higher net returns and improved soil fertility. The data obtained can be helpful in developing nutrient management plans for bidi tobacco grown on Vertisols with medium available soil $\mathrm{P}_{2} \mathrm{O}_{5}$ and high available soil $\mathrm{K}_{2} \mathrm{O}$.

\section{REFERENCES}

Bozhinova, R. (2016). Effect of long term phosphorus fertilization on the mineral composition of oriental tobacco.

\section{ACKNOWLEDGEMENT}

The authors are grateful to All India Network Project on Tobacco (AINPT), ICARCTRI, Rajamahendravaram and Regional Agricultural Research Station, Nandyal, ANGRAU, Andhra Pradesh for providing the facilities for smooth conduct of the experiment.

\section{Bulgarian Journal of Agricultural Science 22(3): 1-5}

Farooq, M., Husssain, T., Wakeel, A. and Cheema, Z.A. (2014) Differential 
et al.response of maize and mungbean to tobacco allelopathy. Experimental Agriculture 50: 611-624

Hanumantha Rao. A., Gopalakrishna C.V.S.S.V. and Satyanarayanamurthy, B.V.V. (1980) Determination of chlorides in tobacco by auto-analyser. Tobacco Research 7: 92-5.

Harvey, W.R., Stahr, H.M. and Smith, W.C. (1969) Automated determination of reducing sugars and alkaloids in the same extract of tobacco.Tobacco Science 13: 13-5.

Hoyos, V. C., Magnitskiy, S. and Plaza, G.T. (2015) Effect of fertilization on the contents of macronutrients and chlorine in tobacco leaves cv. flue-cured (Nicotiana tabacum L.) in two municipalities in Huila, Colombia. Agronomy Colombia 33: 174-183.

Jackson, M.L.(1973) Soil Chemical Analysis. Prentice Hall of India Private limited, New Delhi

Lisuma, J., Mbega, E. and Ndakidemi, P. (2020) Influence of tobacco plant on macronutrient levels in sandy soils. Agronomy 10: 1-15

Moula, M.S., Hossain, M. S., Farazi, M.M., Ali, M.H. and Mamun, M.A.A. (2018) Effects of consecutive two years tobacco cultivation on soil fertility status at Bheramara Upazilla in Kushtia District. Journal of Rice Research 6: 190-195.
Panse, V. G. and Sukhatme, P. V. (1985) Statistical Methods for Agricultural workers. ICAR, New Delhi .

Torrecilla, G., Pino. A., Alfonso, P. and Barroso.A. (1980).Metodología para las mediciones de los caracteres cualitativos de la planta de tabaco. Cienc.Téc. Agriculture Tabaco. 3(1):21-61.

Vann, M.C., Fisher, L.R., Jordan, D.L., Smith, W.D., Hardy, D.H. and Stewart, A.M. (2013) potassium rate and application effect on flue-cured tobacco (Nicotiana tabacum L.). Agronomy Journal 105: 304-310.

Vann, M.C., Fisher, L.R., Jordan, D.L., Smith, W.D., Hardy, D.H. and Stewart, A.M. (2012) The effect of potassium rate on the yield and quality of flue-cured tobacco (Nicotianatabacum L.). Tobacco Science 49:14-20.

Yang, T.Z., Lu, L.M., Xia, W. and Fan, J.H. (2007) Characteristics of potassiumenriched, flue-cured tobacco genotype in potassium absorption, accumulation, and in-ward potassium currents of root cortex. Agricultural Science China.6: 1479-1486.

Zhengxiong Z., Chunjian, L., Yuhong, Y. and Fusuo, Z. (2010) Why does potassium concentration in flue-cured tobacco leaves decrease after apex excision? Field Crops Research 116 (1): 86 - 91. 